\title{
Babesia divergens-like organisms from free-ranging chamois (Rupicapra r. rupicapra) and roe deer (Capreolus c. capreolus) are distinct from B. divergens of cattle origin - an epidemiological and molecular genetic investigation
}

\begin{abstract}
In 2005 and 2006, three adult female chamois (Rupicapra r. rupicapra) were found dead with signs of acute babesial infection in the eastern Swiss Alps. PCR on DNA extracted from blood or spleen of the carcasses revealed sequence identity of the amplified part of the 18S rRNA gene with GenBank entries attributed to Babesia divergens of cattle origin or B. capreoli of wild ruminant origin which have never been described before in this region. Examination of 424 blood samples from 314 head of cattle from this area by IFAT, microscopy and PCR provided no evidence for babesial infection. Six of 887 ticks collected from cattle were PCR-positive, and sequencing revealed Babesia sp. genotype EU1 in five and B. divergens/B. capreoli in one of them. A Babesia isolate of chamois, two isolates of roe deer from the same region and one isolate of a roe deer from the north-western Swiss Alps were genetically compared with two Swiss B. divergens isolates of cattle origin by analysing the genomic rDNA locus. Whereas the near full length sequences of the 18S rRNA gene were virtually identical among all six isolates $(>99.4 \%$ identity), distinct differences between the two isolates from cattle on the one hand and the four isolates from free-ranging ruminants on the other hand were observed in the sequences of the internal transcribed spacers 1 and 2 (ITS1, ITS2) and part of the 28S rRNA gene. These results indicate that, albeit genetically very closely related, these babesial organisms from cattle and from free-ranging ruminants indeed are distinguishable organisms with different host specificities, and they support the use of the discrete species name B. capreoli for the B. divergens-like organisms from chamois and roe deer.
\end{abstract}


Institut für Parasitologie

der Vetsuisse-Fakultät Universität Zürich

Direktor: Prof. Dr. P. Deplazes

Arbeit unter Leitung von PD Dr. Sc. nat. ETH Alexander Mathis

Babesia divergens-like organisms from free-ranging chamois (Rupicapra r. rupicapra) and roe deer (Capreolus c. capreolus) are distinct from $B$. divergens of cattle origin - an epidemiological and molecular genetic investigation

\author{
Inaugural-Dissertation \\ zur Erlangung der Doktorwürde der \\ Vetsuisse-Fakultät Universität Zürich
}

vorgelegt von

Nicole Schmid

Tierärztin

von Dietwil AG, Schweiz

genehmigt auf Antrag von

PD Dr. sc. nat. ETH Alexander Mathis, Referent

Prof. Dr. med. vet. Regina Hofmann-Lehmann, Korreferentin

Zürich 2008

Zentrale der Studentenschaft 
Babesia divergens-like organisms from free-ranging chamois (Rupicapra r. rupicapra) and roe deer (Capreolus c. capreolus) are distinct from $B$. divergens of cattle origin - an epidemiological and molecular genetic investigation

Nicole Schmid ${ }^{a}$, Peter Deplazes ${ }^{a}$, Stefan Hoby ${ }^{b}$, Marie-Pierre Ryser-Degiorgis ${ }^{b}$, Renate Edelhofer ${ }^{c}$, Alexander Mathis ${ }^{a_{*}}$

anstitute of Parasitology, Vetsuisse Faculty, University of Zurich, Winterthurerstrasse 266a, CH-8057 Zurich, Switzerland; ${ }^{b}$ Centre for Fish and Wildlife Health, Institute of Animal Pathology, Vetsuisse Faculty, University of Berne, Länggassstrasse 122, 3001 Berne, Switzerland, 'Departement of Parasitology and Zoology, University of Veterinary Medicine, Veterinärplatz 1, A-1210 Vienna, Austria.

*corresponding author

Tel.: ++41 4463585 01, Fax ++41446358907

Email: alexander.mathis@access.uzh.ch 


\begin{abstract}
In 2005 and 2006, three adult female chamois (Rupicapra r. rupicapra) were found dead with signs of acute babesial infection in the eastern Swiss Alps. PCR on DNA extracted from blood or spleen of the carcasses revealed sequence identity of the amplified part of the 18S rRNA gene with GenBank entries attributed to Babesia divergens of cattle origin or $B$. capreoli of wild ruminant origin which have never been described before in this region. Examination of 424 blood samples from 314 head of cattle from this area by IFAT, microscopy and PCR provided no evidence for babesial infection. Six of 887 ticks collected from cattle were PCR-positive, and sequencing revealed Babesia sp. genotype EU1 in five and $B$. divergens/B. capreoli in one of them. A Babesia isolate of chamois, two isolates of roe deer from the same region and one isolate of a roe deer from the north-western Swiss Alps were genetically compared with two Swiss $B$. divergens isolates of cattle origin by analysing the genomic rDNA locus. Whereas the near full length sequences of the 18S rRNA gene were virtually identical among all six isolates (>99.4\% identity), distinct differences between the two isolates from cattle on the one hand and the four isolates from freeranging ruminants on the other hand were observed in the sequences of the internal transcribed spacers 1 and 2 (ITS1, ITS2) and part of the 28S rRNA gene. These results indicate that, albeit genetically very closely related, these babesial organisms from cattle and from free-ranging ruminants indeed are distinguishable organisms with different host specificities, and they support the use of the discrete species name $B$. capreoli for the $B$. divergens-like organisms from chamois and roe deer.
\end{abstract}

Key words: Babesia capreoli; B. divergens; chamois; roe deer; cattle; ticks; genotyping. 


\section{Introduction.}

In June 2005 and May 2006, three adult female chamois (Rupicapra r. rupicapra) were found dead in the eastern Swiss Alps. Pathological examination revealed pale mucous membranes and musculature, swollen spleen and haemoglobinuria. Blood smears showed small inclusions in the erythrocytes, and PCR/sequencing on DNA extracted from blood or spleen of the infected animals identified the causing organism as Babesia divergens/B. capreoli by a 99\% -100\% identity of a 385-404bp portion of the18S rRNA gene with GenBank entries attributed to these organisms. This was the first confirmed report of fatal Babesia infections in chamois, raising the question of an emerging disease in this species (Hoby et al., 2007a).

The presence of a small Babesia sp. considered as $B$. bovis was described once in a chamois from Switzerland (Bouvier, 1965), but species identification was based only on microscopical examination of blood smears. In other European countries, Babesia $s p$. were reported in free-ranging roe deer (Capreolus c. capreolus), red deer (Cervus elaphus) (Duh et al., 2005b) and a farmed reindeer (Rangifer t. tarandus) (Langton et al., 2003) which were genetically most similar to $B$. divergens, the known pathogen of cattle. The authors suggested that wild ruminants might act as possible reservoirs for $B$. divergens. In earlier studies, small Babesia $s p$. isolated from roe deer were considered a separate species (B. capreoli) based mainly on the fact that this organism was not infective to splenectomized cattle, sheep and goat (Enigk and Friedhoff, 1962). A few subsequent reports on babesial infections of wild ruminants in Europe referred to this species (Dorrestein et al., 1996; Gray et al., 1991). However, B. capreoli currently cannot be adequately differentiated by morphological, serological or molecular means from B. divergens (Garcia-Sanmartin et al., 2007). The only two sequences of $B$. capreoli (AY726009, AY726010) deposited in GenBank show $99.6 \%$ identity (558/560 bp) with part of the 18S rRNA gene of a $B$. divergens isolate from cattle (GenBank accession nr. U07885).

In Switzerland, B. divergens has been described sporadically in cattle of southern and western Switzerland based on microscopical diagnosis (Aeschlimann et al., 1975; Galli-Valerio and Stalder, 1918; Gern et al., 1982), and its occurrence was recently confirmed by molecular means (Mathis et al., 2006, Hilpertshauser et al., 2007, and own unpublished data).

The first report of a $B$. divergens/capreoli-like parasite in a new host (chamois) in a new area (eastern Switzerland) tempted us to investigate whether the parasite is 
present in cattle and/or ticks from cattle in this Swiss region, and to further genetically characterise and compare it with $B$. divergens originating from Swiss cattle.

\section{Material and Methods}

\subsection{Study area}

The region of interest is a rugged, pre-alpine area of about $80 \mathrm{~km}^{2}$ in eastern Switzerland ('Tössstock', 47 $19^{\circ} \mathrm{N}, 8^{\circ} 90^{\prime} \mathrm{E}$ ) comprising grassland and forest. The altitude of the investigated area ranges from 600 to $1300 \mathrm{~m}$ above sea level. Several pastures are shared by cattle and free-ranging ruminants such as roe deer, red deer and chamois as observed by the local farmers and game wardens.

\subsection{Cattle}

Three-hundred and fourteen head of cattle were sampled for this study originating from totally 56 farms. Fourteen farms (F1-14) with 122 animals are located in the study area. The other 42 farms are located outside but their cattle $(n=192)$ grazed on six different pre-alpine pastures (A1-A6) of the study area during summer 2006. Earmark numbers, gender and date of birth were systematically registered. Thirtyfour animals were younger than one year, 196 animals were between one and three years old, and 84 were older than three years. Except for five animals, all investigated cattle were females.

\subsection{Blood samples}

EDTA-blood samples ( $7 \mathrm{ml}$ blood/cattle) were drawn from the vena jugularis externa. From the cattle $(n=122)$ living year-round in the region of interest, blood was taken once; from the animals of the pre-alpine pastures, blood samples were collected at the beginning $(n=140)$ and at the end $(n=162)$ of the summer grazing season.

\subsection{Serology}

After centrifugation (1500 x $\mathrm{g}$ for $15 \mathrm{~min}$ ) of the blood samples, plasma was examined for specific antibodies against $B$. divergens by the indirect fluorescent antibody test (IFAT) using slides coated with $B$. divergens-infected gerbil erythrocytes (fixed for $10 \mathrm{~min}$ in ice-cold acetone and air-dried) and a goat anti-bovine fluoresceinconjugate (Southern Biotech, Reinach BL, Switzerland) diluted 1:200 in PBS (Edelhofer et al., 1998). Serum of a cow originating from a $B$. divergens-free area 
was used as a negative control. The positive control serum of a calf with confirmed $B$. divergens infection was used at dilutions ranging from 1:160 to 1:320, negative and field sera were tested using dilutions from 1:40 to 1:80. The positive threshold titer was set at 1:40. Slides were examined at a final magnification of $600 \mathrm{x}$ using a standard UV-microscope (Olympus BH2) equipped with a 60x oil-immersion objective.

\subsection{Microscopy and DNA extraction}

From all blood samples, one Giemsa-stained smear was prepared (Fluka, BielBenken, Switzerland). DNA isolation from blood was done with the QIAmp DNA blood mini kit (Qiagen AG, Basel, Switzerland) according to the manufacturer's instruction. DNA extraction of ticks was done as described previously (Hilpertshauser et al., 2006).

\subsection{Tick sampling}

During spring, summer and autumn 2006, 887 ticks were collected from 138 head of cattle. Of these ticks, 606 originated from the pre-alpine pasture "A6". Only cattle from this location were examined twice for ticks. Ticks were stored in $70 \%$ ethanol at $4^{\circ} \mathrm{C}$. Species, stage and gender of each tick were determined under the stereo microscope according to the key of the University of Neuchâtel (Cotty, 1985). For DNA isolation, ticks from individual host animals were pooled in groups of maximum 3.

2.7 B. divergens and B. divergens/capreoli-like isolates

Specifications of the parasite isolates investigated are compiled in Table 1.

\subsection{Polymerase chain reaction (PCR)}

PCRs were done in $100-\mu \mathrm{l}$ assays containing buffer $(50 \mathrm{mM} \mathrm{KCl}, 20 \mathrm{mM}$ Tris- $\mathrm{HCl} \mathrm{pH}$ 8.4, $2.5 \mathrm{mM} \mathrm{MgCl} 2,0.5 \%$ Tween 20), each deoxynucleoside triphosphate at a concentration of $0.2 \mathrm{mM}$ (with dUTP replacing dTTP) (all reagents from SigmaAldrich, Buchs, Switzerland), each primer at a concentration of $1 \mu \mathrm{M}$, and $0.5 \mathrm{U}$ uracil DNA glycosylase to control for PCR carryover contamination (Longo et al., 1990) and $5 \mu \mathrm{l}$ (ticks/blood) or $25 \mu \mathrm{l}$ (blood) DNA sample. An initial step at $37^{\circ} \mathrm{C}$ for 10 min was performed in an automatic thermal cycler (DNA engine, MJ Research, Waltham, MA). 
After 10 min of heat inactivation of the uracil DNA glycosylase, $2.5 \cup$ Taq polymerase was added in a hot start.

Primer specifications and cycling conditions are given in Table 2. To check whether amplifiable DNA from ticks was extracted, the tick-specific primers $16 \mathrm{~S}+1$ and $16 \mathrm{~S}-1$ were employed. Identification of Babesia spp. was done by PCR and sequencing of part of the $18 \mathrm{~S}$ rRNA gene; genotyping was achieved by targeting the rRNA genes locus.

The amplified fragments were visualized by electrophoresis on a $1.5 \%$ agarose gel containing ethidium bromide.

\subsection{Cloning and sequencing of amplicons}

Amplicons of repeated PCRs including dTTP were purified either directly or after excision from agarose gels using commercial kits (qiaquick PCR purification kit; min elute gel extraction kit, Qiagen, Hilden, Germany) following the manufacturer's instruction. Sequencing by a private company (Microsynth, Balgach, Switzerland) was done on the cloned amplicons (topo TA cloning-vector pCR 2.1, Invitrogen, Carlsbad, CA). Sequences determined in this study are deposited in the GenBank database (accession numbers EU182594-EU182603).

\subsection{Sequence analyses}

Sequences were subjected to BLAST searches in GenBank, and neighbour-joining trees were constructed in combination with the bootstrap method (van de Peer and de Wachter, 1993), using the aligned sequences (MultiAlin) (Corpet, 1988).

\section{Results}

\subsection{Blood samples from cattle}

From all the 424 tested blood samples, two samples originating from animals of farm "F7" showed a positive titer (1:160) in the IFAT. However, microscopical and PCR examinations using primers Bab_F/R (Table 2) of all the cattle $(n=10)$ of this farm were negative. Further, all animals of the pre-alpine pasture "A6" $(n=30)$ from which ticks with positive Babesia-PCR were identified (see below) were repeatedly tested by IFAT (to check for seroconversion) with consistently negative results. 


\subsection{Ticks}

\subsubsection{Ticks species}

All the collected ticks belonged to the genus Ixodes, and 853 were identified as Ixodes ricinus. Identification to the genus level only was possible with 34 ticks (all Ixodes). The overwhelming majority of the ticks were adult stages $(n=880)$ and 7 were nymphs.

\subsubsection{Detection of babesial DNA in ticks by PCR}

Among the 887 analysed ticks, DNA of Babesia sp. was detected in 6 samples. Sequence analysis of the amplicons obtained with primers Bab_F/R (Table 2) revealed that 5 isolates clustered together with Babesia sp. genotype EU1 (99-100\% identity). The sixth isolate (Z6) had a sequence identical to GenBank entries attributed to $B$. divergens/B. capreoli. All infected ticks were adult females of $I$. ricinus collected from cattle summering on the pasture "A6".

\subsection{Analysis of the 18S rRNA gene}

Full length (1728 bp, isolates B1, B2, C1) or nearly full length (1621 bp, isolate D1) sequences of the 18S rRNA gene revealed identities higher than $99 \%$ among the Babesia isolates from cattle (B1, B2), chamois (C1) and roe deer (D1). A total of 19 polymorphic sites were present with 17 being unique to single sequences, and at two positions (positions 631 and 1637) the sequences of the two isolates from cattle were identical but differed from the identical sequences from the isolates of the freeranging ruminants. A dendrogram using the sequence of the closely related $B$. odocoilei (GenBank AY046577) as outgroup clustered the bovine isolates together apart from the other two isolates. However, the topology of the tree was only weakly supported by bootstrapping (not shown).

3.4 Analysis of rDNA internal transcribed spacers 1 and 2 (ITS1, ITS2), 5.8S and part of the 28S rRNA genes

An approx. $940 \mathrm{bp}$ fragment spanning the ITS1 and 2 and including the full $5.8 \mathrm{~S}$ and part of the 28S rRNA genes was amplified (using primers ITS_F/R; Table 2), cloned and sequenced of all 6 isolates listed in Table 1. Repeated sequencing of 6 clones of the isolates B2 (of cattle origin) and C1 (chamois) revealed no sequence heterogeneity within one isolate. A robust dendrogram could be derived clearly separating the sequences of the Babesia isolates of cattle from those of chamois and 
roe deer (Fig. 1). Three sites could be identified which are clearly distinct between these two groups of genotypes (Fig. 2). PCR and sequencing of part of this target (using primers ITS2_F/28S-rev, Table 2) revealed that the Babesia isolate from a tick (Z6) with an 18S rRNA gene similar to $B$. divergens/B. capreoli (see above) clusters with the isolates from the free-ranging ruminants.

\section{Discussion}

The emergence of lethal infections in chamois caused by a Babesia divergens/capreoli-like parasite in the eastern Swiss Alps (Hoby et al., 2007a) raised fears that the cattle parasite $B$. divergens had expanded its geographical distribution unnoticed and that it had spilled over to wildlife or, vice versa, that it had been introduced to the area by migrating game and constitutes a threat to local cattle. However, neither the microscopical and the serological nor the molecular examinations gave evidence that cattle in this region were infected with Babesia sp. Furthermore, clinical signs of bovine babesiosis have never been observed by the local farmers $(n=48)$, the 4 persons in charge of the 6 pre-alpine pastures, the veterinarians $(n=13)$ or the game wardens $(n=2)$.

Our molecular genetic analyses of these "small" Babesia from cattle and free-ranging ruminants (chamois, roe deer) showed that their nearly full-length $18 \mathrm{~S}$ rRNA genes have very high identities (>99.4\%). In contrast, Babesia sp. EU1 which has repeatedly been identified in game or in ticks in Europe (Casati et al., 2006; Duh et al., 2005a; Duh et al., 2005b; Hilpertshauser et al., 2006 and this work) and which also has been reported in three splenectomized human patients (Haselbarth et al., 2007; Herwaldt et al., 2003), differs by $3 \%$ in this gene sequence. The analyses of part of the $28 \mathrm{~S}$ rRNA gene and of the more variable locus, the rDNA ITS, revealed again a high similarity, but the isolates from cattle could clearly be differentiated from those of free-ranging ruminants (Fig. 2). Hence, these data indicate that $B$. divergens-like organisms from cattle and from free-ranging ruminants are closely related but distinguishable and have different host specificities. These findings confirm earlier observations of different infectivity of such isolates for Mongolian gerbils (Meriones unguiculatus) and cattle which are susceptible to isolates originating from cattle but not to those from game (Gray, 2006; Langton et al., 2003). Hence, these genetic and biological differences support the use of the discrete 
species name B. capreoli (Enigk and Friedhoff, 1962) for the B. divergens-like organisms from chamois and roe deer.

Whether the few human infections which were attributed to $B$. divergens in the past (reviewed by Gray, 2006; Zintl et al., 2003) were caused by Babesia sp. EU1, B. divergens of cattle or $B$. capreoli of wild ruminant origin remains to be determined, and the rDNA locus with the genetic differences reported here seems a useful marker to differentiate the latter two.

Roe deer in Europe seems to host at least two different Babesia sp. namely $B$. capreoli and Babesia sp. EU1, and first studies revealed prevalences of up to $30 \%$ (Bonnet et al., 2007; Duh et al., 2005b; Hoby et al., 2007b). Interestingly, the parasites seem to have a low virulence in roe deer, and it may be speculated that roe deer acts as a reservoir for the parasite affecting chamois. The Babesia isolate from a fatal case in chamois is closely related to three isolates from roe deer of different geographic areas in Switzerland (Fig. 1). Further investigations are required to assess whether these differences are of biological importance or whether chamois is more susceptible to this parasite.

\section{Acknowledgments}

Many thanks to Jeannine Hauri, Felix Grimm, Isabelle Tanner, Sandra Stäbler, Simon Rüegg (Institute of Parasitology, University of Zurich) for their kind support in the laboratory work and to all the farmers for taking part in this study. We thank Max Stacher, Peter Spörri and Peter Schwendimann for sample collection of free-ranging ruminants.

This work was financially supported by the Swiss Federal Veterinary Office and represents the dissertation of Nicole Schmid, veterinarian.

\section{References}

Aeschlimann, A., Brossard, M., Quenet, G., 1975. Contribution to the knowledge of Swiss piroplasms. Acta Trop. 32, 281-289.

Black, W.C., Piesman, J., 1994. Phylogeny of hard- and soft-tick taxa (Acari: Ixodida) based on mitochondrial $16 S$ rDNA sequences. Proc. Natl. Acad. Sci. U.S.A. $91,10034-10038$. 
Bonnet, S., Jouglin, S., L'Hostis, M., Chauvin, A., 2007. Babesia sp. EU1 from roe deer and transmission within Ixodes ricinus. Emerg. Infect. Dis. 13, 12081210.

Bouvier, G., 1965. Observations on the diseases of game and wild animals in 1963 and 1964 [French]. Schweiz. Arch. Tierheilkd. 107, 634-647.

Casati, S., Sager, H., Gern, L., Piffaretti, J.C., 2006. Presence of potentially pathogenic Babesia sp. for human in Ixodes ricinus in Switzerland. Ann. Agric. Environ. Med. 13, 65-70.

Corpet, F., 1988. Multiple sequence alignment with hierarchical clustering. Nucleic Acids Res. 16, 10881-10890.

Cotty, A., 1985. Clé de determination des Ixodidae et Amblyommidae de Suisse. Ph.D. thesis. Université de Neuchâtel, Switzerland.

Dorrestein, G.M., Jongejan, F., Rijpkema, S., 1996. Survey of tick related problems in roe deer (Capreolus capreolus) in The Netherlands. Vet. Q. 18, 148.

Duh, D., Petrovec, M., Avsic-Zupanc, T., 2005a. Molecular characterization of human pathogen Babesia EU1 in Ixodes ricinus ticks from Slovenia. J. Parasitol. 91, 463-465.

Duh, D., Petrovec, M., Bidovec, A., Avsic-Zupanc, T., 2005b. Cervids as Babesiae hosts, Slovenia. Emerg. Infect. Dis. 11, 1121-1123.

Edelhofer, R., Kanout, A., Schuh, M., Kutzer, E., 1998. Improved disease resistance after Babesia divergens vaccination. Parasitol. Res. 84, 181-187.

Enigk, K., Friedhoff, K.T., 1962. Babesia capreoli n. sp. beim Reh (Capreolus capreolus L). Tropenmed. Parasitol. 13, 8-20.

Galli-Valerio, B., Stalder, H., 1918. Bovine piroplasmoses in Switzerland [French]. Schweiz. Arch. Tierheilkd. 60, 471-477.

Garcia-Sanmartin, J., Aurtenetxe, O., Barral, M., Marco, I., Lavin, S., Garcia-Perez, A.L., Hurtado, A., 2007. Molecular detection and characterization of piroplasms infecting cervids and chamois in Northern Spain. Parasitology 134, 391-398.

Gern, L., Brossard, M., Aeschlimann, A., Broquet, C.-A., Quenet, G., Stucki, J.-P., Ackermann, J., 1982. Piroplasmose bovine dans le Clos-du-Doubs (Jura, Suisse): observations préliminaires. Schweiz. Arch. Tierheilkd. 124, 549-556.

Gray, J.S., 2006. Identity of the causal agents of human babesiosis in Europe. Int. J. Med. Microbiol. 296 (Suppl 40), 131-136. 
Gray, J.S., Murphy, T.M., Waldrup, K.A., Wagner, G.G., Blewett, D.A., Harrington, R., 1991. Comparative studies of Babesia spp. from white-tailed and sika deer. J. Wildl. Dis. 27, 86-91.

Haselbarth, K., Tenter, A.M., Brade, V., Krieger, G., Hunfeld, K.P., 2007. First case of human babesiosis in Germany - Clinical presentation and molecular characterisation of the pathogen. Int. J. Med. Microbiol. 297, 197-204.

Herwaldt, B.L., Caccio, S., Gherlinzoni, F., Aspock, H., Slemenda, S.B., Piccaluga, P., Martinelli, G., Edelhofer, R., Hollenstein, U., Poletti, G., Pampiglione, S., Loschenberger, K., Tura, S., Pieniazek, N.J., 2003. Molecular characterization of a non-Babesia divergens organism causing zoonotic babesiosis in Europe. Emerg. Infect. Dis. 9, 942-948.

Hilpertshauser, H., Deplazes, P., Schnyder, M., Gern, L., Mathis, A., 2006. Babesia spp. identified by PCR in ticks collected from domestic and wild ruminants in southern Switzerland. Appl. Environ. Microbiol. 72, 6503-6507.

Hilpertshauser, H., Deplazes, P., Meli, M.L., Hofmann-Lehmann, R., Lutz, H., Mathis, A., 2007. Genotyping of Babesia bigemina from cattle from a non-endemic area (Switzerland). Vet. Parasitol. 145, 59-64.

Hoby, S., Robert, N., Mathis, A., Schmid, N., Meli, M., Hofmann-Lehmann, R., Lutz, H., Deplazes, P., Ryser-Degiorgis, M.-P., 2007a. Babesiosis in free-ranging chamois (Rupicapra r. rupicapra) from Switzerland. Vet Parasitol 148, 341345.

Hoby, S., Schmid, N., Mathis, A., Deplazes, P., Robert, N., Ryser-Degiorgis, M.-P., 2007b. Epizootiological investigations after fatal Babesia sp. infection in chamois from Switzerland. Verh. Ber. Erkrg. Zootiere 43, Edinburgh, 42-44.

Langton, C., Gray, J.S., Waters, P.F., Holman, P.J., 2003. Naturally acquired babesiosis in a reindeer (Rangifer tarandus tarandus) herd in Great Britain. Parasitol. Res. 89, 194-198.

Longo, M.C., Berninger, M.S., Hartley, J.L., 1990. Use of uracil DNA glycosylase to control carry-over contamination in polymerase chain reactions. Gene 93, $125-$ 128.

Mathis, A., Hilpertshauser, H., Deplazes, P., 2006. Piroplasms of ruminants in Switzerland and zoonotic significance of Babesia [German]. Schweiz. Arch. Tierheilkd. 148, 151-159. 
van de Peer, Y., de Wachter, R., 1993. TREECON: a sofware package for the construction and drawing of evolutionary trees. Comput. Applic. Biosci. 9, 177182.

Zahler, M., Schein, E., Rinder, H., Gothe, R., 1998. Characteristic genotypes discriminate between Babesia canis isolates of differing vector specificity and pathogenicity to dogs. Parasitol. Res. 84, 544-548.

Zintl, A., Mulcahy, G., Skerrett, H.E., Taylor, S.M., Gray, J.S., 2003. Babesia divergens, a bovine blood parasite of veterinary and zoonotic importance. Clin. Microbiol. Rev. 16, 622-636. 
Figure 1. Dendrogram deduced from sequences comprising internal transcribed spacer 1 (ITS1), 5.8S rRNA gene, ITS2 and part of 28S rRNA gene of Babesia isolates from Switzerland (isolates B1, B2 from cattle, C1 from chamois, D1D3 from roe deer). Neighbour-joining analysis with bootstrap values of 1000 replicates given at the nodes. No corresponding sequence is known from a closely related organism.

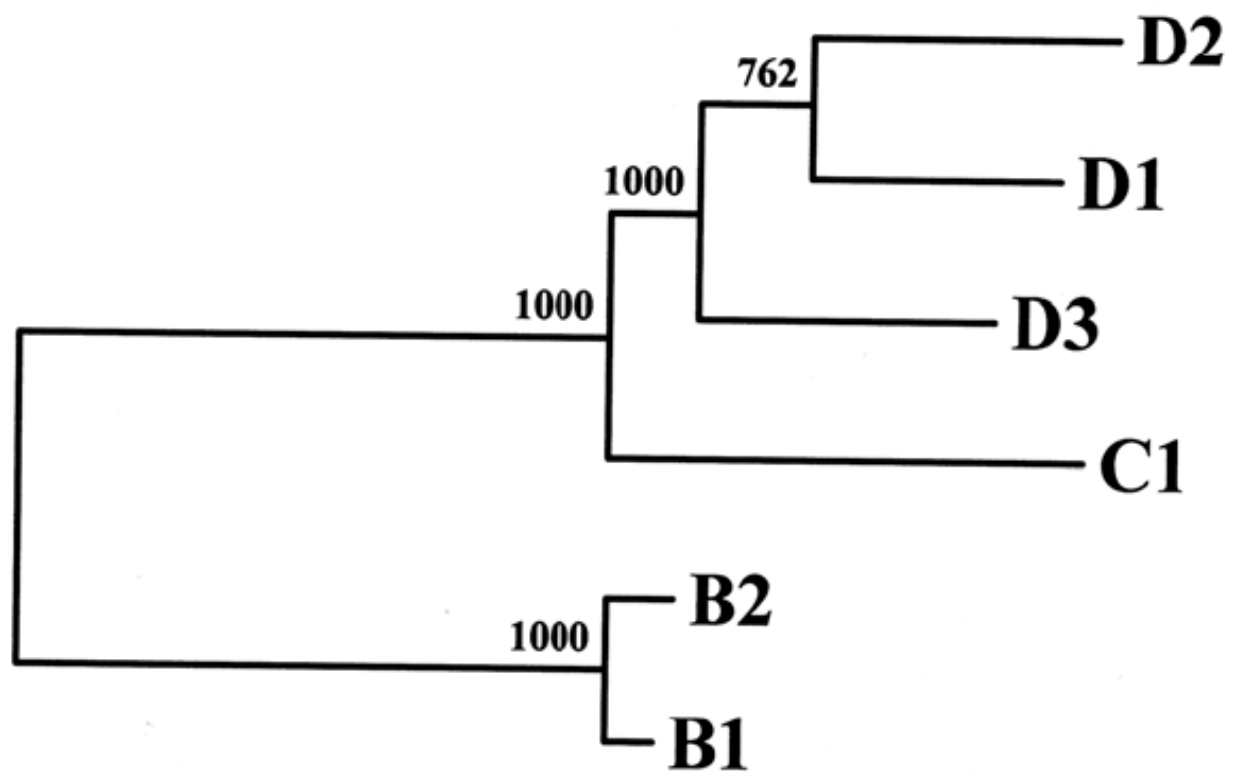


Figure 2. Characteristic sequence differences of rDNA internal transcribed spacers 1 and 2 (ITS1, 2) and 28S rRNA gene of Babesia isolates from cattle (B1, B2), chamois (C1), roe deer (D1, D2, D3) and a tick (Z6). Sequence positions indicated refer to the sequence B1 (GenBank accession nr. EU182598). Dots indicate gaps, differing nucleotides are underlined.

\begin{tabular}{|c|c|c|c|}
\hline & ITS1 & ITS2 & 28S rRNA gene \\
\hline Positi & 230 & 630 & 790 \\
\hline Isolate & -- & & \\
\hline B1 & TGTAGTTGGCGTACACTTGG & СТTTTACT-------CCTGGTAA & АTTACTATTGCAGTATTTCTA \\
\hline B2 & TGTAGTTGGCGTACACTTGG & CTTTTGCT------CCTGGTAA & ATTACTGTTGCAGTATTTCTA \\
\hline C1 & TGTAGTTGATATACACTTGG & CTTTAACTGGTTACTCTGGTAT & AтTACтAтTG---тАттTCTA \\
\hline D1 & TGTAGTTGATATACACTTGG & CTTTTACTGGTTAACTCTGGTAT & АТтАСтАтTG---ТАтTTСтA \\
\hline D2 & TGTAGTTGATATACACTTGG & СTTTTACTGGTTTACTCTGGTAT & ATTACTGTTG---TATTTCTA \\
\hline 3 & TGTAGTTGATATACACCTGG & CTTTAACTGGTTAACTCTGGTAT & АТтАСтАтTG---ТАтTTСтА \\
\hline & (not determined) & ACTCTGGTAT & ---ТАТтTСТА \\
\hline
\end{tabular}


Table 1. Designation and origin of the investigated Babesia isolates.

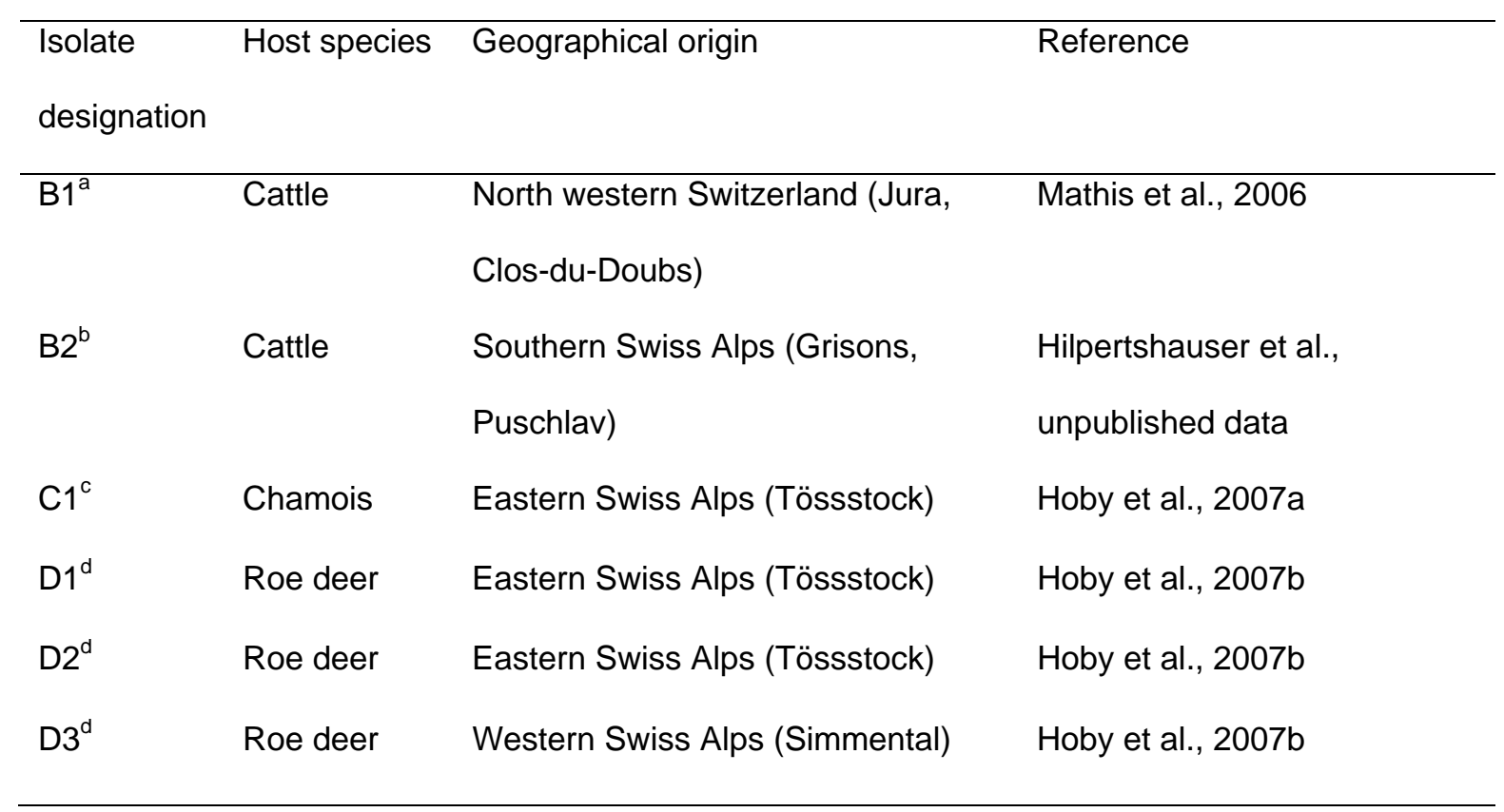

aObtained from a cow living in a known endemic region of $B$. divergens.

${ }^{b}$ Obtained from a splenectomized calf which was infected with the blood of a cow infected with $B$. divergens.

'Obtained from a chamois found dead with clinical signs of acute babesiosis.

dObtained from roe deer collected by game wardens in regions where fatal babesiosis in chamois has been reported 
Table 2: Features of PCR primers used in this study and reaction conditions

\begin{tabular}{|c|c|c|c|c|c|c|c|c|}
\hline $\begin{array}{c}\text { Primer } \\
\text { designations }\end{array}$ & Specificity & Locus & Sequence (5'-3') & $\begin{array}{l}\text { Fragment } \\
\text { size }(b p)\end{array}$ & $\begin{array}{l}\text { Annealing } \\
\text { temp }\left({ }^{\circ} \mathrm{C}\right)\end{array}$ & $\begin{array}{l}\text { Extension } \\
\text { time (s) }\end{array}$ & $\begin{array}{l}\text { No. } \\
\text { cycles }\end{array}$ & Reference \\
\hline $16 S+1 /-1$ & Ticks & $\begin{array}{l}\text { Part of } \\
\text { mitochondrial } \\
\text { 16S rRNA } \\
\text { gene }\end{array}$ & $\begin{array}{l}\text { CTGCTCAATGATTTTTTAAATTGCTGTGG } \\
\text { TTACGCTGTTATCCCTAGAG }\end{array}$ & $\sim 300$ & 62 & 45 & 40 & $\begin{array}{l}\text { (Black and } \\
\text { Piesman, } \\
\text { 1994), } \\
\text { modified }\end{array}$ \\
\hline BAB_F/R & $\begin{array}{l}\text { Babesia } \\
\text { spp. }^{\text {a }}\end{array}$ & $\begin{array}{l}\text { Part of } 18 S \\
\text { rRNA gene }\end{array}$ & $\begin{array}{l}\text { GTTTCTGMCCCATCAGCTTGAC } \\
\text { CAAGACAAAAGTCTGCTTGAAAC }\end{array}$ & $422-440$ & 62 & 45 & 40 & $\begin{array}{l}\text { (Hilpertshauser } \\
\text { et al., 2006) }\end{array}$ \\
\hline CRYPTO_F/R & $\begin{array}{l}\text { Generic } \\
\text { apicomplexa }\end{array}$ & $\begin{array}{l}\text { Complete } \\
\text { 18S rRNA } \\
\text { gene }\end{array}$ & $\begin{array}{l}\text { AACCTGGTTGATCCTGCCAGT } \\
\text { GCTTGATCCTTCTGCAGGTTCACCTAC }\end{array}$ & -1700 & 65 & 90 & 45 & $\begin{array}{l}\text { (Herwaldt et } \\
\text { al., 2003) }\end{array}$ \\
\hline DON_F/R & $\begin{array}{l}\text { Babesia } \\
\text { spp. }^{\text {b }}\end{array}$ & $\begin{array}{l}\text { Nearly } \\
\text { complete } \\
\text { 18S rRNA } \\
\text { gene }\end{array}$ & $\begin{array}{l}\text { TGTCTAAGTACAAACTTTTTAC } \\
\text { TTAAGTGATAAGGTTCACAAG }\end{array}$ & $\sim 1660$ & 56 & 90 & 45 & $\begin{array}{l}\text { (Duh et al., } \\
\text { 2005a), } \\
\text { modified }\end{array}$ \\
\hline ITS_F/R & $\begin{array}{l}\text { Babesia } \\
\text { spp. }^{\text {c }}\end{array}$ & $\begin{array}{l}\text { Part of rRNA } \\
\text { locus }^{\text {d }}\end{array}$ & $\begin{array}{l}\text { GTGAACCTTATCACTTAAAGG } \\
\text { TTC }(A, G) C T C G C C G(C, T) T A C T\end{array}$ & $\sim 940$ & 51 & 90 & 40 & $\begin{array}{l}\text { (Zahler et al., } \\
\text { 1998), } \\
\text { modified }\end{array}$ \\
\hline
\end{tabular}




\begin{tabular}{|l|l|l|l|l|l|l|l|}
\hline $\begin{array}{l}\text { ITS2_F/28S- } \\
\text { rev }\end{array}$ & $\begin{array}{l}\text { Part of rRNA } \\
\text { locus }^{f}\end{array}$ & $\begin{array}{l}\text { CCCGTTTCAGTGAGCCCCCTTTCC } \\
\text { CTTAAATTCAGCGGATAGCCTCAC }\end{array}$ & 314 & 66 & 40 & This study \\
\hline
\end{tabular}

${ }^{a}$ Bovine Babesia spp. (B. divergens, B. bigemina, B. major), Babesia sp. genotype EU1, B. odocoilei, B. canis, B. ovata, B. motasi, and $B$. crassa

${ }^{\mathrm{b}}$ Bovine Babesia spp (B. divergens, B. bigemina, B. bovis), Babesia sp. genotype EU1 , B. odocoilei, B. caballi, B. gibsoni

${ }^{\mathrm{c}}$ forward primer targets conserved sequence of Babesia spp. (B. canis, B. bigemina, B. bovis, B. caballi, B. divergens, B. equi, B. microti, B. odocoilei, B. rodhaini); reverse primer targets 28S RNA gene region highly conserved among eukaryotes.

d internal transcribed spacer 1 (ITS1), 5.8S rRNA gene, ITS2, part of 28S rRNA gene.

${ }^{\mathrm{e}}$ internal primers to fragments obtained with primers ITS_F/R with isolates from this study

${ }^{\mathrm{f}}$ ITS2, part of 28S rRNA gene. 
Name

Geburtsdatum

Nationalität

Heimatort

$1987-1992$

$1992-1993$

$1993-2000$

$2000-2005$

2005

$2006-2007$

Seit Juni 2007
Nicole Henriette Schmid

12. Juni 1980

Schweizerin

Dietwil AG

Primarschule in Adligenswil (LU)

Sekundarschule in Adligenswil

Kantonsschule in Luzern (Matura Typus B)

Studium der Veterinärmedizin an der VetsuisseFakultät Universität Zürich, Schweiz

Staatsexamen an der Vetsuisse-Fakultät Universität Zürich, Schweiz

Doktorarbeit am Institut für Parasitologie an der Vetsuisse-Fakultät Universität Zürich, Schweiz

Assistentin in der Gemischttierpraxis von Dr. med. vet. M. Duss in Escholzmatt, Schweiz 